\title{
The Assassination of Fakhrizadeh-A Major Iranian Counterintelligence Failure?
}

\author{
Ardavan Khoshnood
}

\begin{abstract}
Summary: The assassination of Iranian top nuclear scientist Mohsen Fakhrizadeh is one of numerous assassinations in Iran conducted by foreign powers ever since 2007. In the past six months, assassins have in addition to Fakhrizadeh also been able to kill Al-Qaida's no. 2 on Iranian soil. The three most important organizations in the Iranian intelligence community are the Ministry of Intelligence, as well as the Intelligence Organization and Intelligence Protection Organization of the Islamic Revolutionary Guard Corps. There is no doubt that the assassination of Fakhrizadeh is a counterintelligence failure; however, there are indications that the Iranian intelligence community have been compromised. The assassins of Fakhrizadeh had accurate information about Fakhrizadeh and his security details. Because of this breach, Iran will conduct serious reforms in its intelligence community and may also eliminate individuals it suspects work on behalf of foreign powers and may have leaked information.
\end{abstract}

$\mathrm{T}$

he recent assassination of Iranian nuclear scientist and high-profiled member of the Islamic Revolutionary Guard Corps (IRGC), Brigadier General Mohsen Fakhrizadeh, is yet a sign of the Islamic republic of Iran's poor counterintelligence. Since the beginning of 2007, Iran has witnessed seven targeted killings and one attempted assassination in the country. Seven of these attacks have targeted Iranian nuclear scientists, while one was directed against a leader of Al-Qaida. Only in the past six months, one Al-Qaida leader and one high-profiled nuclear scientist have been assassinated in the Tehran province. Have the Iranian intelligence community been compromised?

\section{A Review of Targeted Attacks}

\section{Ardeshir Hosseinpour}

(January 15, 2007)

Born in 1962, Hosseinpour was a nuclear physicist. He was found dead on January 15, 2007, in his house. Authorities stated that his death was because of "gassing" as a result of a "defect in the heating system" of his residence (Kayhan 2007). On November 30, 2020, Mostafa Moein, former Minister 
of Science, revealed on his Instagram page that Hosseinpour was assassinated by Mossad using radioactive gas (Haghighatnejad 2020).

\section{Masoud Alimohammadi (January 12, 2010)}

Born in 1959, Alimohammadi was a physics professor. In the early morning of January 12, 2010, as he was leaving his residence, a motorcycle equipped with a remote-controlled bomb exploded and fatally injured him (Javanan Online 2010). In December 2010, the Ministry of Intelligence announced that it had arrested the perpetrator, one Majid Jamali Fashi, 24-years old. He "confessed" on television working for Mossad, and was hanged for the crime, in May 2012.

\section{Majid Shahriari}

(November 29, 2010)

Born in 1966, Shahriari was a nuclear scientist and employee of the Atomic Energy Organization of Iran. On the morning of November 29,2010, he and his wife were picked up by their driver. A motorcyclist drove close to the car and planted a bomb which detonated, killing Shahriari (Mashregh News 2020a). The Ministry of Intelligence arrested Maziar Ebrahimi, who, under heavy torture, "confessed" on television to the assassination (Gol 2019). He was later proved innocent and freed (Tabnak 2019).

\section{Fereydoon Abbasi}

(November 29, 2010)

Born in 1958, Abbasi is a nuclear physicist who previously headed the Atomic
Energy Organization of Iran. He is currently a member of the Iranian parliament. On the morning of November 29, 2010, Abbasi was driving his car with his spouse in the passenger seat, when a motorcyclist planted a bomb on the door (Asr-e Iran 2011a). Abbasi stopped the car, and both he and his wife fled the car as the bomb detonated, only injuring the couple. Iran blamed Mossad (Sanger \& Broad 2011).

\section{Dariush Rezaeinejad}

(July 23, 2011)

Born in 1977, Rezaeinejad was an electrical engineer who cooperated with the Ministry of Defense (BBC 2011). Rezaeinejad was assassinated on the evening of July 23, 2011. He was sitting in his car, outside of his house, together with his wife and their daughter, when two motorcyclists started shooting (Asr-e Iran 2011b). Five bullets were fired, of which one fatally injured him. His wife was injured, but survived. Iranian officials blamed Israeli Mossad for the assassination (Putz 2011).

\section{Mostafa Ahmadi Roshan}

(January 11, 2012)

Born in 1979, Ahmadi Roshan was a nuclear scientist and worked as "commerce deputy of the Natanz nuclear power plant" (Tabnak 2018). On the morning of January 11, 2012, he was picked up by his driver, and while driving on the streets of Tehran, a motorcyclist planted a bomb on Ahmadi Roshan's car door, which detonated and killed him. Iran, via its Supreme Leader, Ali Khamenei, blamed both the CIA and the Mossad (The Times 2012). 
Abu Muhammad Al-Masri

(August 7, 2020)

Born in 1963, Abdullah Ahmad Abdullah, better known as Abu Muhammad Al-Masri, was Al-Qaida's number 2. He lived in a prosperous area of Tehran with his family. On the August 7, 2020, Al-Masri and his daughter Maryam were gunned down by two men on a motorcycle (Goldman et al. 2020). $\mathrm{Al}$-Masri and Maryam were sitting in a car outside of their residence. Iran claimed that the killed man was a Lebanese history professor (Mashregh News 2020b).

\section{Mohsen Fakhrizadeh \\ (November 27, 2020)}

Born in 1958, Fakhrizadeh, a nuclear scientist, and a high-ranking member of the IRGC, was considered to be the architecture of the Islamic regime's nuclear program. At the time of his assassination, he headed the Organization of Defensive Innovation and Research. The details of his assassination are still unknown, but he was gunned down on November 27, 2020, as he drove-well guarded-in the city of Absard. Iran instantly blamed Israel (Zarif 2020).

\section{Iranian Counterintelligence}

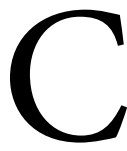

ounterintelligence in Iran, for unknown reasons, is called Intelligence Protection. The two main intelligence and security organizations in Iran, are the Ministry of Intelligence (MOI) as well as the Intelligence Organization of the Islamic Revolutionary Guard Corps (IO-IRGC). While the MOI has a central department of intelligence protection, it is believed that it has also intelligence protection units inside its different departments as well. The IRGC has-parallel to the IO-IRGC-the Intelligence Protection Organization of the Islamic Revolutionary Guard Corps (IPO-IRGC). The IPO-IRGC became independent from the IO-IRGC in the mid-1980s as Iran understood the importance of counterintelligence and started to invest in that discipline. Since then, the two organizations work closely together but fully independently from each other.

The incumbent head of the MOI is the clergyman Mahmoud Alavi. The IO-IRGC is since more than a decade, also headed by a clergyman, Hossein Taeb. The IPO-IRGC is currently headed by Brigadier General Mohammad Kazemi. The Minister of Intelligence is selected by the president but must be approved by the Supreme Leader of the Islamic Republic, Ali Khamenei. The heads of the IO-IRGC and IPOIRGC, however, are directly appointed by Khamenei himself. While the IOIRGC gathers both domestic and foreign intelligence, the IPO-IRGC is foremost responsible for counterespionage, counterterrorism, and safeguarding the IRGC from penetration (Khoshnood 2020a, 7).

In an attempt to coordinate the Iranian intelligence and security apparatus, the Islamic regime created the "Council for Intelligence Coordination" on 29 October 2013 (Mousavi 2018). The council is headed by the Minister of Intelligence and engulfs nine intelligence and security organizations, 
among them the MOI, the IO-IRGC, and the IPO-IRGC. The fact that the IPO-IRGC is presented as an independent organization parallel to MOI and IO-IRGC, illuminates its important role in the Iranian intelligence community.

The current Chief Justice of Iran, Ebrahim Rayisi, recently visited the headquarter of the IPO-IRGC and stated that even though the IRGC as a whole have been of utmost importance for the strength of the Islamic Republic in Iran, the role of the IPO-IRGC has been far more important and sensitive (Mashregh News 2020c).

Interestingly, neither the MOI, nor the IO-IRGC or the IPO-IRGC, are responsible for the executive protection of high-ranking officials of the Islamic regime. It is instead a third organization inside the IRGC, the Protection Organization (PR-IRGC), which is responsible for this task. The PR-IRGC has a three-folded responsibility: (1) protection of the country's airports and airplane security, (2) protection of high-profiled members of the regime, and (3) protection of the Supreme Leader. The protection of high-ranking Iranian nuclear scientists is thus the responsibility of the PR-IRGC. The responsibility of safeguarding the PRIRGC, lies though on the shoulders of the IPO-IRGC.

Even though information from the MOI, IO-IRGC, and IPO-IRGC is used by the PR-IRGC to organize, plan, and direct their protection for individuals under their responsibility, it is the duty of the IPO-IRGC to guarantee the safeguarding of the IRGC's intelligence, including those provided to the PRIRGC.

With so many assassinations and assassination attempts in Iran since 2007 against high-profile individuals of the regime, there is no doubt that Iran has suffered numerous counterintelligence failures (Khoshnood 2020b). In assassinating the aforementioned individuals, several clandestine teams have over a period of time been able to freely follow, map, and organize their attacks without the regime's intelligence organizations being able to reveal the plans or even stop them. Not even when the assassinations started and the regime's intelligence community became aware of the threats could they take the necessary measures to protect their assets. Thirteen years after the first assassination, when Ardeshir Hosseinpour was killed, opponents of the Islamic regime were able to not only assassinate Al-Qaida's number 2 in Iran, but also Iran's most important and valued nuclear scientist (Khoshnood 2020c).

\section{More than a Counter- intelligence Failure?}

fter the assassination of Ar-
deshir Hosseinpour, many
blamed Mossad (Melman 2007). However, the Fars News Agency (2007), which is linked to the IRGC, wrote that Mossad had no role in this assassination, since "the Israeli intelligence agency is basically incapable of running operations inside Iran." Rear Admiral Ali Shamkhani, current Secretary of the powerful Supreme Council of National Security, claimed in a pre- 
vious speech that " $\mathrm{t}] \mathrm{h}$ here are no threats against any officials in the Islamic republic. Listen to me, I am responsible for the security of the country, and it was in the 80s the Monafeghin [the Mojahedin] were able to assassinate. They cannot do that anymore. Adding to that, we have a strong intelligence organization, a strong police force, and a strong revolutionary guard corps. Why are you afraid? We must get rid of close protection" (YouTube 2020). Yet opponents of the regime as well as foreign powers have been able to both assassinate important individuals on Iranian soil, as well as conducting high-quality operations like the Israeli raid against an IRGC warehouse in Tehran in 2018, which contained highly secretive information on Iranian nuclear program (Perper 2018).

After the assassination of Fakhrizadeh, a major blow to the regime and its intelligence apparatus, several different accounts of his slaying have been reported. Initially, regime media stated that Fakhrizadeh was gunned down by several assassins (Fars News Agency 2020). This was later confirmed by the Ministry of Defense (Defa News 2020). The Commander-in-Chief of the Iranian military, Amir Hatami, stated later that Fakhrizadeh was killed because of injuries he received after that a car exploded during the shootout (Mehr News 2020). The latest information though state that no assassins were present during the assassination, and that Fakhrizadeh was killed by a remote-controlled weapon placed on a car which later exploded (BBC 2020). Probably more narratives will be pre- sented during the coming months, which is part of the regime's strategy in confusing the public.

Also as part of regime's propaganda, in a very awkward interview, on the day of Fakhrizadeh's burial, Ali Shamkhani stated that "our enemies have been wanting to kill Fakhrizadeh for 20 years, but they were not successful." In discussing the regime's intelligence apparatus, he stated that "[o]ur intelligence community knew that he [Fakhrizadeh] would be assassinated, and also knew the probable location of the assassination." Shamkhani then added that the threat against Fakhrizadeh had not been taken seriously, which is why enemies had succeeded in assassinating him this time. He then continued, saying "I want to tell you that our intelligence community had the information that he would be assassinated, and that he would be assassinated on the exact spot which he became a martyr on." Interestingly, Shamkhani concludes his remarks saying, "There were made reinforcements with regard to his bodyguards, but this time the enemy used a new approach, more sophisticated and more professional, why they succeeded" (Mizan News 2020).

Shamkhani did not elaborate on why the assassination was not stopped if the Iranian intelligence community were well aware of not only the threat against Fakhrizadeh, but also knew the exact location of where he would be assassinated. Not surprisingly, most of Shamkhani's remarks are solely for propaganda use. However, his statement about being surprised by a new 
approach and therefore not being able to protect Fakhrizadeh may very well be true, and in that case, one very important question arises: Was the assassination of Fakhrizadeh more than just a counterintelligence failure?

In a short note by Brigadier General Hossein Alaei (2020), a high-ranking member of the IRGC, Alaei writes that Fakhrizadeh's assassination indicated that Israeli intelligence is highly active in Iran and operates on "accurate information." Alaei asks how it is possible that Israel can be successful in its assassinations even though Iran is aware of the threats. He concludes: "[I]t remains to be seen what weakness there is in the structure and mechanisms of Iran's security apparatus."

The most important part of Alaei's short note is the question of "accurate information." How did the assassins know the whereabouts of Fakhrizadeh? How did they know when Fakhrizadeh would arrive in that exact area? How could they know details about Fakhrizadeh's executive protection?
It seems impossible that Fakhrizadeh's assassination was only because of an intelligence failure. Fakhrizadeh was not a regular Iranian nuclear scientist like Hosseinpour, Alimohammadi or Shahriari. Fakhrizadeh could not easily be monitored nor mapped by a surveillance team. Everything points out to one important factor: the Islamic Republic of Iran's intelligence and counterintelligence have been penetrated and thus compromised. High-ranking individuals in the Iranian intelligence community are working with opponents of the Islamic regime and foreign powers. In the coming months, we will with high probability witness a major reform in the Iranian intelligence community and specifically the IPO-IRGC. Most of the reforms will take place in the dark and behind the scenes, but we should not be surprised if individuals from Iranian intelligence are either killed in different accidents or flee Iran for Europe and the U.S.

Ardavan Khoshnood is an Associate Professor of Emergency Medicine at Lund University. $\mathrm{He}$ is also a Criminologist and Political Scientist with a degree in Intelligence Analysis. Currently, he is a non-resident Associate at the Begin-Sadat Center for Strategic Studies. His research focus is the Iranian Ministry of Intelligence, the Islamic Revolutionary Guard Corps and the Iranian foreign policy. Twitter: @ardavank.

\section{References}

Alaei, Hossein. "Israel is still active in Iran." Khabar Online, November 27, 2020. https://www.khabaronline.ir/news/1460293 
Asr-e Iran. 2011a. "Dr. Abbasi's memoirs of his own assassination." November 25, 2011. http://www.asriran.com/000ned

Asr-e Iran. 2011b. "Eyewitness reports of bloody assassination in East Tehran." July 23, 2011. http://www.asriran.com/000jHa

BBC. 2011. "The person assassinated in Tehran was a graduate student of Khajeh Nasir University." July 23, 2011. https://www.bbc.com/persian/iran/2011/07/110723_ 110_tehran_killing

BBC. 2020. "Mohsen Fakhrizadeh: Iran scientist 'killed by remote-controlled weapon."' November 30, 2020. https://www.bbc.com/news/world-middleeast-55128970

Defa News. 2020. "Martyrdom of the head of Organization of Defensive Innovation and Research at the Ministry of Defense during a terrorist operation." November 27, 2020. http://www.defanews.ir/news/\%D8\%B4\%D9\%87\%D8\%A7\%D8\% AF\%D8\%AA-\%D8\%B1\%DB\%8C\%DB\%8C\%D8\%B3-\%D8\%B3\%D8\%A7\%D8\% B2\%D9\%85\%D8\%A7\%D9\%86-\%D9\%BE\%DA\%98\%D9\%88\%D9\%87\%D8\%B4\%D9\%88-\%D9\%86\%D9\%88\%D8\%A2\%D9\%88\%D8\%B1\%DB\%8C-\%D9\%88\%D 8\%B2\%D8\%A7\%D8\%B1\%D8\%AA-\%D8\%AF\%D9\%81\%D8\%A7\%D8\%B9\% D 8 \% AF \% D 8 \% B 1 - \% D 8 \% AC \% D 8 \% B 1 \% D B \% 8C \% D 8 \% A 7 \% D 9 86 \%D8\%B9\%D9\%85\%D9\%84\%DB\%8C\%D8\%A7\%D8\%AA-\%D8\%AA\%D8\% B1\%D9\%88\%D8\%B1\%DB\%8C\%D8\%B3\%D8\%AA\%DB\%8C

Fars News Agency. 2007. "Moussad Incapable of Running Operations in Iran." February 4, 2007. https://web.archive.org/web/20070209220338/http:/english. farsnews.com/newstext.php?nn=8511150571 (Archived link. Original news link deleted.)

Fars News Agency. 2020. "Details of the assassination of martyr Fakhrizadeh in Absard, Damavand." November 27, 2020. http://fna.ir/f18jej

Gol, Zhiar. 2019. "The fate of someone who had confessed to assassinating Iranian nuclear scientists." BBC, August 3, 2019. https://www.bbc.com/persian/iran49222841

Goldman, Adam, Eric Schmitt, Farnaz Fassihi, and Ronen Bergman. 2020. "Al Qaeda's No. 2, Accused in U.S. Embassy Attacks, Was Killed in Iran.” The New York Times, November 13, 2020. https://www.nytimes.com/2020/11/13/world/ middleeast/al-masri-abdullah-qaeda-dead.html 
Haghighatnejad, Reza. 2020. "Revealing 14 years of a national security lie about the first nuclear assassination in Iran." Radio Farda, April 9, 2020. https://www. radiofarda.com/a/30980301.html

Javanan Online. 2010. "New details of the assassination of a professor at the University of Tehran have been announced." January 12, 2010. http://www.Javann.ir/ 000qR5

Kayhan. 2007. "The Forensic Medicine Organization confirmed the death of Ardeshir Hosseinpour due to gassing." March 12, 2007. https://www.magiran.com/ article/1370131

Khoshnood, Ardavan. 2020a. "The Role of the Qods Force in the Foreign Policy of the Islamic Republic of Iran." Central European Journal of International and Security Studies, 14(3):4-33.

Khoshnood, Ardavan. 2020b. "The Al-Masri Assassination: Another Iranian Intelligence Failure." The Begin-Sadat Center for Strategic Studies, Perspective Papers, No. 1825.

Khoshnood, Ardavan. 2020c. "The Assassination of Mohsen Fakhrizadeh: What Are the Iranian Regime's Options?” The Begin-Sadat Center for Strategic Studies, Perspective Papers, No. 1834.

Mashregh News. 2020a. "8 Azar, the anniversary of the martyrdom of Dr. Majid Shahriari, the great Iranian nuclear scientist." November 28, 2020. http://www. mshrgh.ir/1149055

Mashrgeh News. 2020b. "The latest details of the murder of a father and daughter at the Pasdaran Street." August 8, 2020. http://www.mshrgh.ir/1104141

Mashregh News. 2020c. "The role of the IRGC intelligence protection organization in protecting the Islamic system is very important." October 22, 2020. http:// www.mshrgh.ir/1133606

Mehr News. 2020. “Details of Fakhrizadeh's martyrdom.” November 27, 2020. http://www.mehrnews.com/xTcCQ

Melman, Yossi. 2007. "U.S. Website: Mossad Killed Iranian Nuclear Physicist." Haaretz, February 3, 2007. https://www.haaretz.com/1.4959425

Mizan News. 2020. "The intelligence services had predicted the assassination of martyr Fakhrizadeh.” November 30, 2020. https://www.mizanonline.com/002qht 
Mousavi, Zahir. 2018. "Council for Intelligence Coordination: From Establishment to today." Etemad, May 7, 2018. https://www.magiran.com/article/3739661

Perper, Rosie. 2018. "Stunning details reveal how Israel's spy agency pulled off one of the most brazen heists in modern history." Business Insider, May 1, 2018. https:// www.businessinsider.com/how-did-mossad-steal-thousands-of-nuclear-docu ments-from-iran-2018-5? $r=U S \& I R=T$

Putz, Ulrike. 2011. "Mossad Behind Tehran Assassinations, Says Source." Der Spiegel, August 2, 2011. https://www.spiegel.de/international/world/sabotaging-iran-s-nu clear-program-mossad-behind-tehran-assassinations-says-source-a-777899.html

Sanger, David E., and William J. Broad. 2011. "Survivor of Attack Leads Nuclear Effort in Iran." The New York Times, July 22, 2011. https://www.nytimes. com/2011/07/23/world/middleeast/23iran.html

Tabnak. 2018. "Assassination of Mustafa Ahmadi Roshan." May 28, 2018. http:// www.tabnak.ir/003MzE

Tabnak. 2019. "Minister of Intelligence explains Maziar Ebrahimi's allegations." September 3, 2019. http://www.tabnak.ir/003rnp

The Times. 2012. "Supreme Leader blames CIA and Mossad for assassination." January 13, 2012. https://www.thetimes.co.uk/article/supreme-leader-blames-ciaand-mossad-for-assassination-b0wmdmwtdjw

YouTube. 2020. "Ali Shamkhani states that there is no threat against any official of the Islamic Republic of Iran." https://youtu.be/cHCEcJJujCY

Zarif, Javad. 2020. “Terrorists murdered an eminent Iranian scientist today. This cowardice-with serious indications of Israeli role-shows desperate warmongering of perpetrators." Twitter, November 27, 2020. https://twitter.com/JZarif/sta tus/1332345633425022976 